\title{
Notes Toward a Theory of Multilevel Governing in Europe ${ }^{1}$
}

\author{
Fritz W. Scharpf*
}

The complexity of the multilevel European polity is not adequately represented by the singlelevel theoretical concepts of competing 'intergovernmentalist' and 'supranationalist' approaches. By contrast, empirical research focusing on multilevel interactions tends either to emphasize the uniqueness of its objects, or to create novel concepts - which are likely to remain contested even among Europeanists and have the effect of isolating European studies from the political-science mainstream in International Relations and Comparative Politics. These difficulties are bound to continue as long as researchers keep proposing holistic concepts that claim to represent the complex reality of the European polity as a whole. It is suggested that the present competition among poorly fitting and contested generalizations could be overcome if European studies made use of a plurality of simpler and complementary concepts, each of which is meant to represent the specific characteristics of certain subsets of multilevel interactions - which could also be applied and tested in other fields of political-science research. Four distinct modes of multilevel interaction in the European polity are described - 'mutual adjustment', 'intergovernmental negotiations', 'joint-decision making', and 'hierarchical direction' - and their characteristics are discussed by reference to the criteria of problemsolving capacity and institutional legitimacy.

\section{Multilevel Europe - the Case for Multiple Concepts}

The European Union (EU) and its member states have become a multilevel polity whose characteristics are poorly understood in political discourses as well as in academic controversies that are shaped by our conventional understanding of national politics and international relations. In public debates, we typically find unrealistic expectations - fears or hopes - of what European policy might achieve, combined with ignorance of what is in fact achieved, and polemics against the 'democratic deficit' of the institutions and processes through which European policy outcomes are being achieved. There is, in other words, no realistic understanding of the extent and the limitations of either the institutional capacity or the institutional legitimacy of the European polity.

* Fritz W. Scharpf, Max-Planck-Institut fur Gesellschaftsforschung, Paulstraße 3, D-50676 Köln, Germany. 
That is no reason for condescension, however, since the state of affairs in academic political science is not much better. There are, it is true, many highly knowledgeable and perceptive empirical accounts of European institutions and policy processes, but when it comes to theoretical explanations and normative assessments, we still find unresolved controversies between 'neo-functionalist' and 'realist', or 'supranational' and 'intergovernmental' approaches in the opening chapters of every dissertation. One reason is that the conceptual tools with which the political science subdisciplines of international relations and comparative politics are approaching the study of European institutions are ill suited to deal with multilevel interactions.

From the intergovernmental perspective of international relations theory, which presumes that nation states are the only theoretically relevant actors, the EU appears as a - more highly institutionalized - specimen of the genus 'international organization'. Such organizations are created to serve the purposes of their member states; and to the extent that they do so, their actions are legitimated by the agreement of member governments. At the same time, these actions are fully explained by the interests, relative bargaining powers, and bargaining strategies of those governments (Hoffmann 1966; 1982; Garrett 1992; 1995; Moravcsik 1998). In other words, the multilevel polity of the European Union is conceptualized in a single-level model of intergovernmental interactions. ${ }^{2}$

By contrast, students of comparative politics are led by their own disciplinary bias to emphasize the 'supranational' characteristics of the EU, and to analyze its governing institutions as if it were, or ought to be, a polity resembling the models of democratic nation states. To be sure, these models differ greatly in their normative and descriptive characteristics, emphasizing either accountability through competitive or consensual party systems (Lijphart 1999), or the responsiveness of pluralist, corporatist or clientelist systems of interest intermediation (Truman 1951; LaPalombara 1964; Schmitter \& Lehmbruch 1979). In any case, however, the focus is on the interactions between a single, autonomous and potentially omnipotent government and its constituents. Hence normative studies will focus on the relationship between European-level ('supranational') actors and constituents - emphasizing either the lack of democratic accountability (Greven 2000) or the existence (or feasibility) of institutional mechanisms facilitating responsiveness to constituency interests (Abromeit 1998; Eichener 2000; Grande 2000), whereas empirical research will focus either on the salience of European elections and the influence of the European Parliament, or on the channels of successful lobbying at the European level, the representation of 'diffuse' interests, the role of deliberative problem solving in European 'comitology', and the inclusiveness of European 'policy networks' involving business associations, large firms, environmental and 
consumer groups and other NGOs involved in processes of interest intermediation (Mazey \& Richardson 1993; Joerges \& Neyer 1997; Pollack 1997; Joerges \& Vos 1999; Kohler-Koch \& Eising 1999).

Admittedly, our knowledge of the structures, processes and outcomes of European integration was often advanced by good research designed from either one of these competing perspectives. But the continuing controversies between intergovernmental and supranational perspectives suggest that these insights had to be achieved in spite of the poor fit of their paradigmatic assumptions. Thus the intergovernmental international-relations perspective must be pushed to the limits of its plausibility when it is asked to explain constellations where supranational actors are empowered to act against the manifest preferences of member governments; where member states are subject to increasingly tight European constraints in the exercise of their own governing powers; where interactions among their citizens and corporations are increasingly governed by European law; and where the range of problems for which solutions are being sought at the European level seems to increase continuously (Burley \& Mattli 1993; Jachtenfuchs \& Kohler-Koch 1996; Sandholtz \& Stone Sweet 1998; Schmidt 1998; Eichener 2000; Pollack 2000).

Similarly, however, the supranational perspective of comparative-politics theories cannot easily represent a European polity in which member states continue to be endowed with a full range of governing powers; in which the limited competencies of supranational actors are derived from agreement among member states; in which European legislation depends primarily on the agreement of member governments; and in which member states are in control of the actual administration of European regulations (Moravcsik 1998). Nor are these difficulties eliminated in studies approaching the EU from a comparative-federalism perspective (Scharpf 1988; Wessels 1990; Sbragia 1992, 1993; Schmidt 1999; Nicolaidis \& Howse, forthcoming). While this perspective does suggest models that are able to represent the coexistence of, and the interaction between, distinct levels of government, their fit is still quite poor if it should be assumed that European-level government could be equated with the institutional capacity and legitimacy of central governments in federal nation states ${ }^{3}-$ and if that equation cannot be made, federal models also lose much of their explanatory and predictive power. For opposite reasons, that is also true of perspectives equating the EU with models of 'confederal governance' (Wallace 1982; Lister 1996). ${ }^{4}$

In the face of these paradigmatic difficulties, some of the best work on Europe is either self-consciously atheoretical or it attempts to structure research through a variety of innovative concepts and metaphors characterizing the European polity as a 'condominio', a 'consortio', a 'fusion' of governing functions, a structure of 'network governance', and the like 
(Marks et al. 1996; Schmitter 1996; Wessels 1997; Kohler-Koch \& Eising 1999). In general, such concepts do indeed take account of the multilevel nature of European institutions and governing processes, but they also emphasize their uniqueness and thus have the effect of carving out a separate and theoretically distinct domain of 'European Community Studies'. Even within this domain, however, it seems fair to say that many of these novel conceptualizations seem to fit the cases at hand but have not yet found broad acceptance among fellow Europeanists (Branch \& Øhrgaard 1999; Sandholtz \& Stone Sweet 1999), let alone among political scientists who are interested in theoretical propositions of more general applicability.

That seems an unfortunate and unnecessary state of affairs. It is unfortunate because it tends to immunize European studies against theoretical criticism from other quarters while depriving more general political-science theories of the empirical challenges arising from the growing body of research focused on Europe. It also seems unnecessary, since, even if the European polity is sui generis in the sense that there is no other institutional constellation quite like it, it should still be possible to analyze its institutions and policy processes with the use of theory-based concepts and propositions that are also useful in comparative politics and international relations. From what I have said so far, however, it also would follow that the reintegration of European studies into the mainstream of political science cannot be achieved through holistic concepts attempting to equate the EU to any of the reasonably well understood but internally complex macro-models or ideal types that political scientists use as a first cut in distinguishing among political systems.

Certainly, the EU is not a majoritarian or a consociational democracy, but neither are its structures and processes of interest intermediation generally congruent with ideal types like pluralism, corporatism or even network governance, nor do its intergovernmental structures and processes generally conform to the legal models of federation, confederacy or international organization. Instead, I suggest, we should work with a plurality of lower-level and simpler concepts describing distinct governing modes in the European polity - which, however, should also be useful as theoretical modules in studies of national government or international relations. The ones I will discuss here focus on the vertical relationship between European and national levels of government. It is clear that they could and should eventually be complemented by other lower-level concepts focusing on structures and processes of interest intermediation and on the political interactions between governmental actors at both levels and their constituencies. In the present article, however, my focus will be on vertical interactions among governments, which I will describe - in order of increasing supranationalism - as the modes of 'mutual adjustment', 'intergovernmental negotiations', 'joint decision making' and 'hierarchical direction'. 
Moreover, I suggest that we should explain the progressive Europeanization of governing functions by reference to theoretical propositions that are useful for describing and explaining similar upward shifts of governing functions in federal national states or, for that matter, similar processes of political unification involving nation states. ${ }^{6}$ By the same token, I find it important that the institutional capacity and legitimacy of Europeanized governing should be evaluated by reference to the same normative criteria that we generally use for the evaluation of governing institutions.

\section{What Drives Europeanization?}

I begin with a brief discussion of the policy goals and pressures that account for the progressive Europeanization of governing functions from the mid1950 s to the present. Since NATO was by the 1950s taking care of European security interests ${ }^{7}$ - 'keeping the Russians out and the Germans down' the explicit motive driving European integration was economic - or, more precisely, the anticipated benefits for consumers and producers that were thought to be associated with the creation of larger European markets for goods and services, and capital (Moravcsik 1998). ${ }^{8}$

This quest for economies of scale has not only driven the geographic enlargement from the Economic Community of the Six to the present Union of the Fifteen and beyond. It also explains the progress from a free-trade area to a customs union and to a common market eliminating national nontariff barriers to trade (Armstrong \& Bulmer 1998). Moreover, being the only manifest European mission, economic goals became progressively radicalized - moving from the mere integration of national markets as they existed in the mixed economies of member states to an active extension and perfection of market competition. It thus became a European governing function to eliminate national subsidies, public procurement practices and the 'privileges' of public enterprises, public utilities and public services which could be construed as distortions of free market competition. By the same logic, finally, it was thought that the transaction costs imposed by the existence of multiple currencies and variable exchange rates ought to be eliminated by the creation of a monetary union and a common currency (Verdun 1996, 2000; Moravcsik 1998, chapter 6).

Here I will not examine the theoretical validity of these propositions or the empirical magnitude of the economic benefits that can in fact be attributed to the achievements of market integration in Europe (Kamppeter 2000). ${ }^{9}$ What matter much more, from a political science perspective, are the secondary effects of this process. As the primary goals of market integration are being realized, member states find themselves exposed to political pressures of a kind that in federal nation states (which had inte- 
grated national markets to begin with) have everywhere resulted in the progressive centralization of 'market-correcting' governing functions that affected profits and production costs and hence the competitive position of subnational economic regions. Thus practically all federal states have come to regulate the economically salient aspects of work safety, environmental protection, labor law, industrial relations and the welfare state at the national level.

In Europe, the same pressures are reflected in current debates about the erosion of national governing capabilities in integrated European markets where firms may offer their products throughout the EU; where consumers will select goods and services without regard to their origin within the EU; and where capital owners are free to invest, and firms are free to locate their production, anywhere within the territory of the EU. Among the member states of the European Monetary Union (EMU), moreover, these locational choices are not even constrained by the risks of exchange-rate adjustments.

As a consequence, the impacts of national policies affecting aggregate or sectoral demand, average or sectoral production costs, and post-tax profits are no longer limited to the national economy. There may be positive externalities, as when the additional demand generated by a cut of income taxes will spill out to neighboring countries, or when an increase of taxes on capital interest or profits will trigger capital outflows into low-tax jurisdictions. By the same token, negative externalities occur when a major reduction of employers' social security contributions will increase the price competitiveness of national products at the expense of competitors in European product markets, or when similar effects are achieved by union wage restraint or a deregulation of labor markets. It is likely, moreover, that these economic externalities will have political repercussions - as when German truck operators were blocking the streets of Berlin in response to tax reductions on diesel fuel in France and The Netherlands. To the extent that governments are aware of and respond to this European interdependence among their policy choices, it is meaningful to say that the governing functions affected are in fact becoming Europeanized.

\section{Modes of Europeanization}

It makes a great difference, however, whether Europeanization is merely the outcome of strategic actions among governments that are aware of their mutual interdependence - which I describe as the mode of 'mutual adjustment' - or whether Europeanized governing functions are exercised in one of the modes of institutionalized interaction - where I distinguish between the modes of 'intergovernmental negotiations', 'joint decisions' and 'supranational centralization'. In what follows, I will discuss the characteristics 
and consequences of these modes by reference to two evaluative criteria, institutional capacity and institutional legitimacy, both of which need to be understood in a relational sense. The first is used to evaluate the decision rules and incentive structures of Europeanized governing modes in relation to the specific range of problems that are supposed to be resolved through Europeanization. Similarly, the second criterion should be used to evaluate those Europeanized governing functions that are in fact effectively performed in the light of legitimating arguments that are generally considered pertinent for the evaluation of governing institutions at the national level (Lord 1998). Both of these criteria should and could be elaborated further (Scharpf 1999, 2000), but I trust that their intended meaning will become sufficiently clear in the following discussion.

\section{Mutual Adjustment}

The default mode of Europeanized policy responses to increasing economic interdependence is 'mutual adjustment'. Here, national governments continue to adopt their own policies nationally, but they do so in response to, or anticipation of, the policy choices of other governments. Hence these strategic interactions among governments can be analyzed as a non-cooperative game. ${ }^{10}$ In theory and in the real world, there is of course a great variety of possible game constellations. In some of them, the expected outcomes (or equilibria) of strategic interaction are mutually beneficial (Genschel 1997), in others they will benefit some parties at the expense of others, and in still others all parties may be worse off (Rapoport \& Guyer 1966; Rapoport et al. 1976; Scharpf 1997). By the same token, there also cannot be a general verdict on the problem-solving effectiveness of mutual adjustment in Europe.

Economists who are impressed with the benefits of market competition, it is true, would generally ascribe beneficial efficiency effects not only to the competition among political parties, but also to constellations in which mutual adjustment forces national governments to engage in forms of 'systems competition' (i.e. tax competition and regulatory competition) against each other (Sinn 1993; Vanberg \& Kerber 1994). Nevertheless, one should not ignore the important differences between the competition among firms (which presumably benefits all consumers), the competition among political parties (benefiting all voters) and the locational competition between territorial governments - which tends to benefit mobile firms, investors and taxpayers at the expense of the less mobile members of national constituencies, and which reduces the capacity of national governments to perform those market-correcting functions that, in economic theory, justify the establishment of governments in the first place (Sinn 1994; Scharpf 1998). 
Moreover, economic theory tends to discount the effect on democratic self-determination if systems competition should prevent all governments from adopting policies that would reflect the preferences of their constituencies. For example, think of the situation in which the American states found themselves in the early decades of the twentieth century, when even 'progressive' state governments could not adopt legislation limiting the employment of children for fear of losing market shares in interstate commerce. ${ }^{11}$ As the European internal market has approached completion, these same competitive pressures are now constraining member states in taxation, in the regulation of employment relations, in social policy, in the environmental regulation of production processes and in other marketcorrecting policy choices (Scharpf 1999). These constraints may not only reduce the problem-solving effectiveness of national polities; they also affect their institutional legitimacy by preventing the adoption of (otherwise feasible) policies responding to the manifest demands of national electorates (Scharpf 2000).

In response to these tightening constraints, member states have been trying to move away from the mode of mutual adjustment, and to control systems competition through the coordination or centralization of governing functions at the European level. Within the democratic nation state, however, politics at the national level tends to have the greatest political salience and the clearest procedures assuring democratic accountability. Hence a shift of market-correcting governing functions from the subnational to the national level is generally associated not only with a gain in problem-solving capacity but also with a gain in democratic legitimacy. By contrast, neither of these effects is assured when competencies are shifted from the national to the European level. In both regards, moreover, there are significant differences between the three modes of institutionalized European governing functions that I am considering here.

\section{Intergovernmental Negotiations}

At the lowest level of institutionalization, Europeanized governing is realized in the mode of 'intergovernmental negotiations'. Here, national policies are coordinated or standardized by agreements at the European level, but national governments remain in full control of the decision process, none of them can be bound without its own consent, and the transformation of agreements into national law and their implementation remains fully under their control. This is emphatically true of policies requiring Treaty revisions that must be ratified in all member states. Beyond that, the mode applies in the second and third pillars of 'common foreign and security policy' and 'police and judicial cooperation in criminal 
matters', and it is also approximated in those policy areas in the first pillar where the Council of Ministers must still decide by unanimity.

Since all participating governments have a veto, the legitimacy of policies so adopted can be indirectly derived from the legitimacy of democratically accountable national governments (Lord 1998). ${ }^{12}$ By the same token, however, the problem-solving capacity of negotiated policy is strictly limited to solutions that are preferable to the status quo from the perspective of all participating governments. If such solutions are not available, side payments and package deals may still facilitate agreement under favorable circumstances (Scharpf 1997, chapter 6). More generally, however, solutions will be blocked by major conflicts of interest - which is exactly what governments seem to want in the second and third pillars, where sovereignty issues are extremely salient.

For the resolution of problems generated by regulatory and tax competition in the integrated European economies, however, the mode of intergovernmental negotiations seems to offer little promise in all constellations where existing national solutions differ significantly from one another, or where some countries are actually benefiting from competition. If evidence were required, the unending history of efforts to harmonize the taxation of capital interest or of corporate profits through unanimous agreement should suffice. But how, then, did these same governments manage to achieve the degree of market integration that is generating these competitive pressures?

\section{Hierarchical Direction}

In discussing this question, I now turn to 'hierarchical direction', the mode in which competencies are completely centralized at the European level and exercised by supranational actors without the participation of memberstate governments. Within federal nation states, such centralized competencies are generally exercised by majorities in national parliaments, cabinet ministers and prime ministers whose legitimacy is directly derived from electoral accountability. In the European Union, by contrast, functions that are performed without the participation of member governments are also removed from the influence of democratically accountable political actors. They are exercised by the European Central Bank (ECB), by the European Court of Justice (ECJ) and by the European Commission when it is acting as a guardian of the Treaty in infringement procedures against national governments.

Since these functions are exercised without the participation of either the European Parliament or member-state governments, their legitimacy must depend entirely on shared beliefs in the authority of the law and in the capacity of professional authorities to realize shared norms, values or goals (Majone 1989, 1996). For the ECB, these goals were explicitly and quite 
narrowly defined as a commitment to price stability in the Maastricht Treaty (now Article 105 of the EC Treaty), whereas the independent governing powers of the Court and the Commission are derived from their implicit responsibility for interpreting the law of the Treaty in the process of applying it in specific legal proceedings.

Non-democratic legitimacy also plays a role in democratic nation states where constitutional courts, independent central banks or independent regulatory agencies are performing governing functions for which they are thought to be better suited than politically accountable governments. At the national level, however, this form of legitimacy is inherently precarious and would collapse if non-accountable actors should exceed the limits of the 'permissive consensus' on which their governing powers depend (Bickel 1962) - in which case the policy choices of independent actors, or even their institutional independence, would become vulnerable to correction by legislative action or constitutional amendment. ${ }^{13}$ In the European Union, by contrast, such reversals would be much more difficult to achieve. The independence of the European Central Bank is protected by the Maastricht Treaty to a degree that exceeds the institutional autonomy of any national central bank (Elgie 1998; Haan \& Eijffinger 2000), while Treaty-based decisions of the European Court of Justice (ECJ) can be reversed only by Treaty revisions that must be ratified by all member states. Moreover, the ECJ has been able to establish the doctrines of 'direct effect' and 'supremacy' by which its interpretations of European law will override not only acts of government, but also parliamentary legislation and even the constitutions of all member states (Weiler 1982).

In terms of substantive policy, the supranational governing functions exercised by the Court and the Commission have been most effective in policy areas where economic integration could be advanced by applying fairly explicit prohibitions in the treaties against national policies constituting barriers to the free mobility of goods, services, capital and persons or distortions of free competition. In interpreting these rules of 'negative integration', the Commission and the Court have certainly gone beyond the original intent of negotiating parties at the conferences of Messina and Rome (Scharpf 1999, 54-62). Nevertheless, governments have by and large continued to support the moving goal of ever increasing economic integration (Moravcsik 1998), even though the Amsterdam Summit attempted to impose some limits on the reach of European competition law, which, however, have not been very effective.

So how should we judge the problem-solving effectiveness and legitimacy of those governing functions that have been effectively centralized? As for effectiveness in achieving their assigned or self-chosen goals, the record of hierarchical policy choices adopted by the Commission and the Court is indeed impressive. National courts have generally accepted the authority of 
the European Court of Justice as the ultimate interpreter of European law (Burley \& Mattli 1993), and even the German constitutional court has finally abjured its claim to act as a court of last resort when individual liberties are in issue. ${ }^{14}$ As a consequence, European law is routinely enforced in ordinary cases and controversies by the judicial systems of member states. Moreover, this law goes further in eliminating non-tariff barriers to free trade and free movement than is true in long-established federal states like the United States, Australia or Switzerland. Even more significant is the fact that European competition law is effective in imposing much narrower restrictions on public subsidies granted by member states than federal states are imposing on subnational governments (Wolf 2000; Zürn 2000), and that it also is enforcing competition in public services and public utilities that, within nation states, had everywhere been exempted from anti-trust and competition law (Scharpf 1999, chapters 2 and 3).

In short, if there should be reason for concern, it is not about the lack of effectiveness of negative integration, but rather about the single-minded perfectionism with which the ideal of perfectly competitive markets is pursued by the Commission and the Court. ${ }^{15}$ Much the same could be said for the effectiveness of the European Central Bank in assuring price stability among EMU member states. In spite of the recent decline of the euro exchange rate (whose maintenance is not an explicit goal assigned to the ECB), the euro's internal value has remained remarkably stable in comparison with earlier decades, and even in Germany the near-hysterical fears of trading the stable mark against an inflationary euro seem to have abated. If the problem-solving effectiveness of European monetary policy is at all questioned, doubts are primarily voiced in quarters where (contrary to the explicit language of the Treaty) price stability is not considered the only criterion of success.

But what of the legitimacy of centralized European governing functions? Here it is remarkable that concerns about a European democratic deficit have rarely been addressed to those policy areas where Commission and Court were advancing negative integration without the participation of either national governments or the European Parliament. Since these policies are carried out in the form of legal actions, they are by and large accepted with the affirmative support or grumbling respect ${ }^{16}$ with which winners and losers tend to respond to court decisions at the national level. In other words, market-making supranational policies benefited not only from the ascendancy of neoliberal and free-trade doctrines in academe and the media, but also from the customary respect for 'the law' and from the legitimacy credit granted to judicial interpretations in the constitutional democracies of member states.

That is not, or perhaps not yet, generally true of monetary policy and the European Central Bank - mainly because member states differed greatly 
in the extent to which monetary and currency-policy choices had been depoliticized before the creation of the EMU. In countries like Germany, where central bank independence has a long tradition, the worry was that the ECB would be less independent than the Bundesbank, whereas in Britain, Sweden, Denmark and some other member states, the critical issue was precisely the lack of political accountability (Elgie 1998). It seems, however, that the accountability issue is also raised as a proxy for serious concerns about the problem-solving effectiveness of the EMU (Gustavsson 2000). These must be particularly salient in countries that used to rely on devaluation for solving major economic and employment problems. By contrast, the present member states had been part of the European Monetary System before joining the European Monetary Union, and they had learned to live with the constraints of a non-accommodating monetary policy and nearly fixed exchange rates. For them, therefore, the change from a tight money policy defined by the Bundesbank with a view to conditions in the German economy to a tight money policy defined by the ECB with a view to average conditions in Euroland must seem more a promise than a threat. ${ }^{17}$

The implication is that for the most centralized and supranational governing mode of the multilevel European polity neither problem-solving effectiveness nor legitimacy is seriously in question. But in comparison with the full range of public policies that are in place at the national level in advanced capitalist democracies, the reach of the supranational mode is essentially restricted to the market-making enforcement of 'negative integration' by the Commission and the Court and to control over the currency by the European Central Bank. It was not and could not be used to achieve market-correcting 'positive integration' by non-political hierarchical fiat. ${ }^{18}$ Instead, policies that might be effective in dealing with the negative consequences of regulatory and tax competition depend on political regulations, directives and decisions that can be adopted only with the participation of member governments.

\section{Joint Decisions}

The 'joint-decision mode' combines aspects of intergovernmental negotiations and supranational centralization. It applies in most policy areas of the first pillar, which includes the market-making as well as the marketcorrecting competencies of the European Community. Here, European legislation generally depends on initiatives of the Commission which must be adopted (unanimously or by qualified majority) by the Council of Ministers and, increasingly, by the European Parliament. Assessments of the institutional capacity and legitimacy of this mode vary considerably in the academic literature and in political debates - which reflects the fact that policy choices depend, at the same time, on the institutional resources and 
strategies of supranational actors, and on the convergence of preferences among national governments - both of which are likely to vary from one policy area to another.

If member governments are united in their opposition to Commission initiatives, or if highly salient national interests are strongly divergent, European solutions will be blocked, regardless of the involvement of Commission and Parliament. The role of supranational actors will be significant, however, in constellations where national interests diverge but are not highly salient or - more important in theory and practice - in constellations where member governments disagree over the substance of a European solution but still would prefer a common solution over the status quo.

Under these conditions - which can be analytically represented by a battle-of-the-sexes game - common solutions could still be blocked by intergovernmental haggling over the precise content of European rules. It is here, therefore, that qualified majority voting should be most acceptable to governments. By the same token, it is here that the capacity for European action will benefit most from the Commission's agenda-setting monopoly, from the expanding co-decision rights of the Parliament (Tsebelis 1994), from the good services of national representatives in COREPER (HayesRenshaw \& Wallace 1997; Lewis 2000) and from the work of Europeanized national experts in the hundreds of committees preparing, or specifying the details of, Council directives (Joerges \& Neyer 1997; Joerges \& Vos 1999).

By the same token, however, the institutional legitimacy of joint-decision procedures loses its intergovernmental foundation. By the logic of the original treaties, European legislation was primarily legitimated by the agreement of democratically accountable national governments. Yet these legitimating arguments are undermined the more the role of non-accountable supranational actors and procedures is emphasized in the literature and perceived by political actors and their publics. If it is true that infringement proceedings initiated by the Commission can compel national governments to change their positions on politically salient issues (Schmidt 1998), that national representatives in COREPER will conspire to block domestic opposition to European compromises (Lewis 2000), and that comitology favors agreements among national experts that are decoupled from the positions of their governments (Joerges \& Neyer 1997), then the formal agreement of governments in the Council will no longer have much legitimating force.

As a consequence, the focus of legitimating arguments in the literature has shifted. What is now emphasized is the openness of European decision processes to the demands and the expertise of plural interests, the flexibility of European 'networks' of interest intermediation, and the 'deliberative' qualities of interactions in comitology (Jachtenfuchs \& Kohler-Koch 1996; 
Marks \& McAdam 1996; Marks et al. 1996; Joerges \& Vos 1999; KohlerKoch \& Eising 1999; Schmalz-Bruns 1999). Regardless of the descriptive accuracy of these accounts, however, their normative persuasiveness must rest on the proposition that the accommodation of special interests and the substantive quality of European standards could be a legitimating substitute for democratic accountability based on general and equal elections and public debates. But since effectiveness of European policy must frequently be achieved by 'subterfuge' in processes that are completely opaque to the public (Héritier 1999), there is no assurance that all affected interests will even be aware of what is going on at the European level. ${ }^{19}$ For politically salient issues, at any rate, it is thus hard to see how informal networks of interest intermediation and anonymous expert committees could be considered satisfactory substitutes for the democratic accountability of representatives whose mandate is derived, directly or indirectly, from general elections based on the formal equality of all citizens (Weiler 1999; Greven 2000).

In light of these legitimacy problems, it is perhaps good news that the success stories celebrating the effectiveness of supranational mechanisms and the problem-solving capacity of European policy (Eichener 1997, 2000; Pollack 1997) are considerably exaggerated or at least overgeneralized. They are true as far as they go, but their empirical domain is limited to a range of policy areas in which conflict over divergent national interests is overshadowed by a common interest, or where decisions tend to have low political salience for the general public. This is true for market-making directives harmonizing national product regulations ${ }^{20}$ and for a few other policy areas where common interests are stronger than divergent interests (Scharpf 1997, 1999). But where it is not true, national governments remain fully capable of blocking European decisions even if the decision rule is qualified-majority voting in the Council (Golub 1996a, 1996b).

From a legitimacy point of view, therefore, all seems to be well. In the joint-decision mode, the EU can deal only with problems where European action is supported by a broad consensus involving democratically accountable national governments, a directly elected European Parliament and those affected (and organized) interests that are able to influence the agenda-setting functions of the Commission. Where this consensus exists, the legitimacy of policies so adopted is not seriously in question, even though the procedures do not conform to standard models of democratic accountability in the nation state. Where it does not exist, European action is blocked, and problems are left to be resolved by national governments in institutions and procedures with presumably impeccable democratic credentials. But all is not well from a problem-solving perspective if the market-making policies on which Europe can agree will damage the capacity of national governments to adopt those market-correcting policies 
on which the EU cannot agree. Unfortunately, this European problemsolving gap tends to exist in precisely those policy areas where national governing functions are most vulnerable to systems competition.

One reason is that constellations of tax competition and regulatory competition do not generally resemble either a battle-of-the-sexes game or a symmetrical prisoner's dilemma - in which case agreement on common rules regulating competition should be possible. In tax competition, for instance, small countries may actually increase their revenue through tax cuts that bigger countries could not reciprocate without incurring massive revenue losses (Dehejia \& Genschel 1999). Similar asymmetries may favor competitive deregulation in other policy areas. In such constellations, the winners are clearly not interested in having their competitive advantages harmonized away by common European rules. But even in the absence of winner-loser asymmetries, harmonization may be blocked by conflicts arising from politically salient differences among member states in economic development, policy legacies, institutional structures or ideological preferences.

Thus, environmental regulations considered necessary in Denmark, Germany or The Netherlands may simply not be affordable in less wealthy member states like Greece, Spain or Portugal, let alone countries on the threshold of eastern enlargement. The same would be true if the EU attempted to standardize the provision of social transfers and public social services at the level that is considered appropriate in the Scandinavian countries. If that were all, it might perhaps be possible to agree on relative standards reflecting these differences in the ability-to-pay of member states at different stages of economic development. Yet even though Britain and Sweden may be similarly wealthy, they could still not agree on common European welfare-state solutions.

The reason is that European welfare states have come to define widely differing dividing lines between the functions the state is expected to perform and those that are left to private provision, either in the family or by the market. They all provide social assistance to the needy, but in Scandinavia and on the European continent, the state also provides earnings-related social insurance that is meant to secure the standard of living of average-income families in the case of unemployment, sickness and disability, and in old age. In Britain and other Anglo-Saxon welfare states, by contrast, workers with average or higher incomes have learned to rely on private provisions for these eventualities. Moreover, only the Scandinavian welfare states are providing universal and high-quality social services freeing wives and mothers from family duties while at the same time providing the public-sector jobs that have raised female participation in the labor market to record levels. In Continental and Anglo-Saxon countries, by contrast, these services are left to be provided in the family or by the 
market (Scharpf \& Schmidt 2000a). Differences of similar significance are also characteristic of the industrial relations institutions of EU member states (Crouch 1993; Ebbinghaus \& Visser 2000).

These structural differences are not merely of a technical nature but have high political salience. They correspond to fundamentally differing welfarestate aspirations which can be roughly equated with the historical dominance of 'liberal', 'Christian democratic' and 'social democratic' political parties and social theories (Esping-Andersen 1990). Moreover, and perhaps more important, citizens in all countries have come to base their life plans on the continuation of existing models, and any attempts to replace these with qualitatively different European solutions would mobilize fierce opposition. Scandinavian voters would resist the dismantling of their full-service welfare state just as much as British voters would refuse to accept the higher taxes that would be needed to finance the Scandinavian model, and both would reject the German model of tightly regulated industrial relations and codetermination. There is, in short, no single 'European social model' on which harmonization could converge (Ferrera et al. 2000).

In the joint-decision mode, therefore, national governments, accountable to their national constituencies, could not possibly agree on common European solutions for the core functions of the welfare state. That need not prevent the adoption of minimum European standards on social and workers' rights either through Council directives or through agreements reached in the 'social dialogue' of the peak-level organizations of capital and labor (Leibfried \& Pierson 1995; Falkner 1998). But since such standards must be acceptable to all member states, they must not only be economically viable in the least wealthy member states, but also compatible with all existing industrial relations and welfare-state institutions. It is no surprise, therefore, that only very undemanding regulations have been able to pass this dual test (Streeck 1995, 1997) - which also implies that while they may be useful in raising minimal levels of social protection in AngloSaxon and southern countries, they will not do much to relieve the competitive pressures on more advanced Continental and Scandinavian welfare states.

\section{Other Options?}

Under present conditions, therefore, European social policy is able to intervene (in the mode of hierarchical direction) against discriminatory national rules and practices affecting migrant workers and gender equality, and to adopt legislation (in the joint-decision mode) assuring minimal standards of social protection that do not challenge either the ability to pay or the core institutions of member states. Nor could institutional reforms change much 
in this regard. Given the high political salience of national welfare-state institutions, governments must resist all proposals by which differences could be harmonized away through majority decisions in the Council and the European Parliament. The point can be made more generally: the European Union is not, and cannot soon become, a majoritarian democracy (Lord 1998; Scharpf 1999; Greven 2000), and its institutional legitimacy cannot support policies that violate the permissive consensus of constituencies in its member states.

By the same token, however, the problem-solving capacity of the European Union must also remain limited. It was and is sufficient to create and regulate the larger European market, but it is insufficient for Europeanizing those market-correcting governing functions that, at the level of member states, are most vulnerable to the pressures of economic competition. Hence member states must continue to cope with these pressures in the mode of mutual adjustment. What that entails for the survival of advanced European welfare states is the subject of ongoing controversies in public debates and in academic analyses, which I cannot review here (Scharpf \& Schmidt 2000a, 2000b). There is no question that economic globalization and, above all, European economic integration and the EMU have deprived national policy makers of many of the policy options they could and did employ in earlier decades to achieve and defend full employment and high levels of social protection. Moreover, intense competition in international product markets and increased capital mobility are exerting downward pressures on wages as well as on taxes and regulations that would increase the unit costs of production or reduce post-tax profits. Governments and unions that ignore these international pressures will pay for it in terms of lower economic growth and job losses. At the same time, national governments have lost control over interest rates and exchange rates in the EMU, publicsector deficits are constrained by the rules of the Stability Pact and by the anticipated response of international capital markets, and state subsidies are policed under European competition law.

Constraints, however, are just that. They do not rule out strategic choices, and they do not determine outcomes. There are at least some European countries - e.g. Denmark among the Scandinavian welfare states, The Netherlands among the Continental group, and Portugal in the south - that have found ways to achieve or maintain high international economic viability without abandoning their employment and welfare-state aspirations or resorting to beggar-my-neighbor strategies policies that - like devaluation - could only work if others did not follow suit (Ferrera et al. 2000; Scharpf \& Schmidt 2000a). But not all national welfare states have remained economically viable, and many of them are struggling with disruptive political conflicts over tax cuts, welfare retrenchment and employment deregulation. 
Under these conditions, there is reason to ask whether the European Union - which generated these problems for member states without being able to deal with them directly - might nevertheless play a positive role in facilitating successful coping strategies at the national level. In my earlier work (Scharpf 1999, chapter 5), I have discussed two such solutions - the formulation and enforcement of standards of 'unfair regulatory and tax competition' by the Commission and the Court, and what I have called 'sub-European coordination'. In the meantime, the first of these suggestions seems to have become a realistic prospect with the recent announcement by Commissioner Monti that he would henceforth examine selective tax concessions under the rules applying to distortions of competition through state subsidies.

The second suggestion might have a chance if the current Intergovernmental Conference should in fact liberalize the provisions on 'closer cooperation' in Title VII of the Treaty of European Union. In that case, it might become possible that groups of countries that have similar welfarestate institutions and are facing similar problems could use the machinery of the European Union and the services of the Commission to harmonize their social policies. Unfortunately, however, the recent discussion has again raised the specter of an avant-garde of member states moving ahead toward political integration and relegating all others to second-class status. Given the decades of misunderstandings and apprehensions associated with proposals for 'differentiated integration' in a 'Europe with variable geometry', a 'multi-speed Europe', a 'two-tier Europe', a 'Europe à la carte', a 'Europe of concentric circles' or a 'core Europe' (Ehlermann 1984; Giering 1997; Ehlermann 1998; Walker 1998; Búrca \& Scott 2000), there is little hope at the time of this writing (October 2000) that the extremely restrictive rules adopted at the Amsterdam Summit will be significantly liberalized at the upcoming Nice Summit.

But even if selective harmonization should be beyond reach, opportunities for coordinating reform efforts could also be provided by the procedures of 'open coordination' which were introduced in the new 'Employment' title of the EC Treaty at Amsterdam, and which the Lisbon Summit (23-24 March 2000) decided to apply also in the field of social policy. In terms of the concepts used here, open coordination could be located somewhere between the mode of 'intergovernmental negotiations' and the mode of 'mutual adjustment'. It resembles mutual adjustment insofar as governing competencies remain entirely at the national level and continue to be exercised by national governments that remain fully accountable for their policy choices to their national electorates. There are, in other words, no problems of a democratic deficit here. At the same time, however, national policy choices are not to be exercised in isolation. Acknowledging that promoting employment is 'a matter of common concern', governments 
have accepted a commitment to 'coordinate their action in this respect within the Council' (Art. 126, II). For this purpose, the Council acting on a proposal of the Commission will adopt annual guidelines for national action, member states will submit annual reports on actions taken to implement these guidelines, and these will be evaluated by a permanent high-level committee of national civil servants and by the Commission, which may then propose specific recommendations to the Council.

These rules provide for multilevel and recursive processes of joint problem analyses and goal setting, self-commitment and self-evaluation, combined with common monitoring and central benchmarking capacities. Such arrangements appear plausible if it is assumed that member states see themselves pursuing parallel, rather than conflicting goals, but also prefer to remain free in defining and adopting their own measures for reaching these goals - presumably because national conditions are so different or politically salient that uniform solutions could not be effective or politically acceptable. Given that Article 129 explicitly excludes the "harmonization of the laws and regulations of the Member States' from the range of measures that the Council may adopt, the considerable efforts required by the elaborate procedures of open coordination must then be justified by the hope that monitoring, benchmarking and peer review could increase the effectiveness of national employment and social policies (Ferrera et al. 2000, chapter 4).

At a theoretical level, that is not implausible (Sabel 1995). The question is, however, whether these promises of 'policy learning' can be fully realized under the heterogeneous conditions shaping the employment and social policy problems as well as the policy options of EU member states. ${ }^{21}$ From what was said above, it would follow that 'open coordination' will be most effective if aspirations for Europe-wide standards of performance are moderated by the recognition that member states may legitimately differ not only in the policy instruments they employ, but also in the goals they strive to attain and in the problems they need to deal with. In that case, the potential gains from coordination and policy learning will be the greater, the more countries with similar institutions and policy legacies are encouraged to cooperate in focusing on their specific problems and potential solutions to them.

At this time, it is too early to tell whether these efforts will remain at the level of symbolic politics and public relations or will have real effects on national policies. ${ }^{22}$ Nevertheless, 'open coordination' does appear to be a potentially valuable addition to the set of institutionalized governing modes that are available in the European polity. It is more flexible than either joint decisions or intergovernmental negotiations. In comparison with mutual adjustment, it could nevertheless provide useful safeguards against unintended races to the bottom under conditions of systems competition. If taken seriously by national governments, it could become an important 
European response to the pressures on national welfare states that were brought about by European economic integration.

To conclude: the European polity is a complex multilevel institutional configuration that cannot be adequately represented by theoretical models that are generally used in international relations or comparative politics. Worse yet, its complexity also seems to defy all theoretical efforts based on holistic concepts. The present article suggests that these difficulties could be overcome by a modular approach using a plurality of simpler concepts representing different modes of multilevel interaction which are characteristic of subsets of European policy processes. I have tried to show that these modes exist and that they have specific implications for the institutional capacity and legitimacy of European governing functions. My further claim (which was not developed here) is that the same conceptual tools should also be useful for the analysis of subnational, national, transnational and other supranational policy-making institutions.

\section{NOTES}

1. This article is the enlarged version of a lecture presented on the occasion of receiving the Johan Skytte Prize in Political Science on 30 September 2000 at Uppsala University.

2. Moravcsik's $(1993,1998)$ 'liberal intergovernmentalism', it is true, also has a domestic module attached in which the preferences of national governments are shaped by the interests of major national producer groups, which, however, are not assumed to be actors in their own right on the European level.

3. The distortion is most pronounced if the federalist perspective is defined by reference to the 'separation' model of the US constitution. But even if it is realized that European institutions are structurally similar to the German model of 'joint-decision' federalism (Scharpf 1988; Sbragia 1992, 1993), parallels are misleading. Though European legislation - like most important national legislation in Germany - depends on the agreement of member governments, the political characteristics of vertical interactions differ fundamentally, since the democratic legitimacy and the bargaining resources of the national government and parliament in Germany are so much greater than those of the European Commission and the European Parliament.

4. Lister acknowledges as much: 'At the same time, the European Union, while clearly falling within the broad class of confederations, differs in fundamental ways from earlier confederal models. It has legislative, executive, judicial and financial capabilities that they did not have and that allow its institutions to operate much more effectively' (Lister 1996, 107).

5. These concepts correspond to the 'modes of interaction' discussed in Scharpf 1997. The list is not complete, however, since the mode of 'majority voting' does not - and cannot (Lord 1998; Scharpf 1999) - play the same central legitimating role in the European polity which we have come to associate with majority rule in democratic nation states.

6. For an early and still convincing attempt to explain European integration through concepts and propositions claiming general applicability to processes of 'political unification', see Etzioni 1965.

7. These would otherwise have provided very powerful motives for federation (Riker 1964).

8. This is not meant to deny the crucial role that European integration has played in creating conditions where, for the first time in history, war among European countries has become unthinkable. As economic boundaries have been removed, moving political boundaries between member states has ceased to be a salient national goal. 
9. These economic benefits of integration may exist, but they are not easy to demonstrate empirically. In the macro-economic crises of the 1970s, small European countries outside of the Common Market (e.g. Sweden, Austria, Switzerland) were doing better than Denmark, The Netherlands and Belgium; and just as the Single Market program was being completed in 1992, the member states of the EU were hit by the deepest postwar recession (Scharpf \& Schmidt 2000b).

10. As I have pointed out elsewhere, even constellations where governments merely adjust their own policies to economic conditions affected by the interdependent policy choices of other governments can usefully be analyzed as a non-cooperative game (Scharpf 1997, 107-12).

11. In fact, child labor legislation in the United Sates (along with other regulations of employment conditions, social security and other welfare-state policies) had to wait until the 1937 New Deal revolution in American constitutional law, which then allowed the federal government to adopt uniform national regulations (Skocpol 1987).

12. Strictly speaking, that is only true for the initial agreement. Once a common policy has been adopted, it can be changed only by unanimous intergovernmental agreement. Hence individual governments are no longer able to respond to new circumstances or changing constituency preferences (Scharpf 1988).

13. The historical cause célèbre is President Rooseveldt's 'court packing plan' of 1937, which caused the US Supreme Court to reverse its line of anti-New-Deal decisions. It should also be noted that the much celebrated independence of the German Bundesbank was never protected against ordinary legislation.

14. Bundesverfassungsgericht 2 BvL 1/97, 6 June 2000.

15. That is certainly the view of the German Länder which, in the run-up to the Nice Summit, even threatened to block eastern enlargement in the absence of Treaty amendments protecting their infrastructure functions against European competition policy.

16. That may be about to change as the discretionary character of extensive interpretations of European competition law and their lack of political legitimation are publicly asserted by (sub)national political actors in cases where interventions by the Commission are clashing with politically salient (sub)national industrial, infrastructure and cultural policies. In Germany, these clashes give rise to double-pronged demands for institutional reforms increasing the democratic accountability of the Commission and limiting the scope of its competencies.

17. A potentially more serious challenge to the problem-solving effectiveness of ECB monetary policy arises from the fact that the EMU is not an 'optimal currency area', and that economic conditions, and phases of the business cycle, may significantly differ among member states. Since the ECB can respond only to average conditions, its actual policy may turn out to be either too tight or too loose for the economies of particular member states. The latter problem is currently faced by Ireland, where inflation runs twice as high as the Euro average - with the consequence that uniform nominal Euro interest rates will translate into negative real interest rates for consumers and investors in Ireland. Under these conditions, it is at least uncertain whether union wage restraint can be relied upon to dampen the inflationary pressures that are exacerbated by the misfit of European monetary policy (Hardiman 2000).

Since the economic consequences of a lack of fit between uniform ECB policy and diverse conditions of national economies must be dealt with by national policy responses, the tightness of the budgetary constraints laid down by the Maastricht Treaty and the subsequent Stability Pact may also interfere with effective problem solving. However, as the Scandinavian countries seem to have been quickest to grasp, there is a functionally equivalent solution to deficit spending: Finland, Sweden and Denmark have built up substantial budget surpluses, which should allow them to respond with vigorous fiscal expansion to future economic downturns without violating any of the EMU constraints.

18. Exceptions are policies promoting gender equality in employment and preventing discrimination against migrant workers, both of which can be directly derived from the Treaty. 
19. Similar claims to legitimacy were advanced by theorists of American pluralism (Truman 1951; Latham 1952), but it is fair to say that they were ultimately rejected on empirical as well as normative grounds (Mills 1956; Dahl 1961, 1967; Bachrach \& Baratz 1963; Olson 1965; McConnell 1966; Lindblom 1977).

20. When that is not true - as in the BSE case or for genetically modified foodstuffs national governments tend to take control again, since it is they, rather than the anonymous experts on the Commission's Veterinary Committee, who must face the brunt of political protest at home.

21. It seems significant that the employment guidelines proposed by the Commission and adopted by the Luxembourg Council for 1998 and the following years seem carefully designed to avoid all issues in which existing differences among the policy legacies and institutional structures of member states would be highly salient, focusing instead on such institution-neutral goals as 'improving employability', 'developing entrepreneurship', 'encouraging adaptability' and 'strengthening policies for equal opportunities' (Council 21-11-97). In Lisbon, the employment goals were amended to include 'lifelong learning' and 'increasing employment in services', and open coordination was extended to cover also the goals of 'modernizing social protection' and 'promoting social inclusion'.

22. Since no binding directives are to be adopted at the European level, actors who are in fact in charge of national policy choices may fail to get actively involved in the coordination exercises. In that case, the danger is that 'National Action Plans' will merely restate what governments are doing anyway, and that the learning effect of deliberations at the European level may only benefit international liaison officials who lack effective power at home.

\section{REFERENCES}

Abromeit, H. 1998. Democracy in Europe. Legitimising Politics in a Non-State Polity. New York: Berghahn Books.

Armstrong, K. A. \& Bulmer, S. J. 1998. The Governance of the Single European Market. Manchester: Manchester University Press.

Bachrach, P. \& Baratz, M. S. 1963. 'Decisions and Nondecisions. An Analytical Framework', American Political Science Review 57, 632-42.

Bickel, A. M. 1962. The Least Dangerous Branch. The Supreme Court at the Bar of Politics. Indianapolis: Bobbs Merril.

Branch, A. P. \& Øhrgaard, J. C. 1999. 'Trapped in the Supranational-Intergovernmental Dichotomy. A Response to Stone Sweet and Sandholtz', Journal of European Public Policy $6,123-43$.

Búrca, G. de \& Scott, J., eds. 2000. Constitutional Change in the EU. From Uniformity to Flexibility? Oxford: Hart.

Burley, A.-M. \& Mattli, W. 1993. 'Europe before the Court. A Political Theory of Legal Integration', International Organization 47, 41-76.

Crouch, C. 1993. Industrial Relations and European State Traditions. Oxford: Clarendon Press.

Dahl, R. A. 1961. Who Governs? Democracy and Power in an American City. New Haven: Yale University Press.

Dahl, R. A. 1967. Pluralist Democracy in the United States: Conflict and Consent. Chicago: Rand McNally.

Dehejia, V. H. \& Genschel, P. 1999. 'Tax Competition in the European Union', Politics and Society 27, 403-30.

Ebbinghaus, B. \& Visser, J. 2000. Trade Unions in Western Europe since 1945. London: Macmillan.

Ehlermann, C.-D. 1984. 'How Flexible Is Community Law? An Unusual Approach to the Concept of "Two Speeds"', Michigan Law Review 82, 1274-93.

Ehlermann, C.-D. 1998. 'Differentiation, Flexibility, Closer Co-operation. The New Provisions of the Amsterdam Treaty', European Law Journal 4, 246-70. 
Eichener, V. 1997. 'Effective European Problem-Solving: Lessons from the Regulation of Occupational Safety and Environmental Protection', Journal of European Public Policy 4, 591-608.

Eichener, V. 2000. Das Entscheidungssystem der Europäischen Union. Institutionelle Analyse und demokratietheoretische Bewertung. Opladen: Leske \& Budrich.

Elgie, R. 1998. 'Democratic Accountability and Central Bank Independence. Historical and Contemporary, National and European Perspectives', West European Politics 21(3), $53-76$.

Esping-Andersen, G. 1990. The Three Worlds of Welfare Capitalism. Cambridge: Polity Press.

Etzioni, A. 1965. Political Unification. A Comparative Study of Leaders and Forces. New York: Holt, Rinehart \& Winston.

Falkner, G. 1998. EU Social Policy in the 1990s. Towards a Corporatist Policy Community. London: Routledge.

Ferrera, M., Hemerijck, A. \& Rhodes, M. 2000. The Future of Social Europe. Recasting Work and Welfare in the New Economy. Oeiras: Celta Editora.

Garrett, G. 1992. 'International Cooperation and Institutional Choice. The European Community's Internal Market', International Organization 46, 533-60.

Garrett, G. 1995. 'The Politics of Legal Integration in the European Union', International Organization 49, 171-81.

Genschel, P. 1997. 'How Fragmentation Can Improve Co-ordination. Setting Standards in International Telecommunications', Organization Studies 18, 603-22.

Giering, K. 1997. 'Vielfalt in Einheit - die Flexibilisierung der europäischen Integration', in Europa Institut Zürich, ed., Die Europäische Union - Wesen, Struktur, Dynamik. Zürich: Schulthess Polgraphischer Verlag.

Golub, J. 1996a. 'Sovereignty and Subsidiarity in EU Environmental Policy', Political Studies 44, 686-703.

Golub, J. 1996b. 'State Power and Institutional Influence in European Integration: Lessons from the Packaging Waste Directive', Journal of Common Market Studies 34, 313-39.

Grande, E. 2000. 'Post-National Democracy in Europe', in Greven, M. Th. \& Pauly, L. W., eds, Democracy Beyond the State? The European Dilemma and the Emerging Global Order. Lanham: Rowman \& Littlefield.

Greven, M. Th. 2000. 'Can the European Union Finally Become a Democracy?', in Greven, M. Th. \& Pauly, L. W., eds, Democracy Beyond the State? The European Dilemma and the Emerging Global Order. Lanham: Rowman \& Littlefield.

Gustavsson, S. 2000. 'What Makes a European Monetary Union without a Parallel Fiscal Union Politically Sustainable?' Ms, Department of Political Science, Uppsala University.

Haan, J. de \& Eijffinger, S. C. W. 2000. 'The Democratic Accountability of the European Central Bank: A Comment on Two Fairy-Tales', Journal of Common Market Studies 38, 393-408.

Hardiman, N. 2000. 'From Conflict to Coordination: Economic Governance and Political Innovation in Ireland'. Ms, Politics Department, University College Dublin.

Hayes-Renshaw, F. \& Wallace, H. 1997. The Council of Ministers. London: Macmillan.

Héritier, A. 1999. Policy-Making and Diversity in Europe. Escaping Deadlock. Cambridge: Cambridge University Press.

Hoffmann, S. 1966. 'Obstinate or Obsolete? The Fate of the Nation State and the Case of Western Europe', Daedalus 95, 892-908.

Hoffmann, S. 1982. 'Reflections on the Nation-State in Western Europe Today', Journal of Common Market Studies 21, 21-37.

Jachtenfuchs, M. \& Kohler-Koch, B., eds. 1996. Europäische Integration. Opladen: Leske \& Budrich.

Joerges, C. \& Neyer, J. 1997. 'Transforming Strategic Interaction into Deliberative Problem Solving: European Comitology in the Foodstuffs Sector', Journal of European Public Policy 4, 609-25.

Joerges, C. \& Vos, E., eds. 1999. EU Committees: Social Regulation, Law and Politics. Oxford: Hart.

Kamppeter, W. 2000. Lessons of European Integration. Bonn: Friedrich Ebert Stiftung. 
Kohler-Koch, B. \& Eising, R., eds. 1999. The Transformation of Governance in the European Union. London: Routledge.

LaPalombara, J. 1964. Interest Groups in Italian Politics. Princeton: Princeton University Press.

Latham, E. 1952. The Group Basis of Politics. Ithaca: Cornell University Press.

Leibfried, S. \& Pierson, P., eds. 1995. European Social Policy. Between Fragmentation and Integration. Washington: Brookings Institution.

Lewis, J. 2000. 'The Methods of Community in EU Decision-Making and Administrative Rivalry in the Council's Infrastructure', Journal of European Public Policy 7, 261-89.

Lijphart, A. 1999. Patterns of Democracy. Government Forms and Performance in Thirty-Six Countries. New Haven: Yale University Press.

Lindblom, C. E. 1977. Politics and Markets. The World's Political-Economic Systems. New York: Basic Books.

Lister, F. K. 1996. The European Union, the United Nations, and the Revival of Confederal Governance. London: Greenwood Press.

Lord, C. 1998. Democracy in the European Union. Sheffield: Sheffield Academic Press.

Majone, G. 1989. Evidence, Argument and Persuasion in the Policy Process. New Haven: Yale University Press.

Majone, G., ed. 1996. Regulating Europe. London: Routledge.

Marks, G. \& McAdam, D. 1996. 'Social Movements and the Changing Structure of Political Opportunity in the European Union', in Marks, G., Scharpf, F. W., Schmitter, P. C. \& Streeck, W., eds, Governance in the European Union. London: Sage.

Marks, G., Hooghe, L. \& Blank, K. 1996. 'European Integration from the 1980s: StateCentric v. Multi-level Governance', Journal of Common Market Studies 27, 63-84.

Mazey, S. \& Richardson, J., eds. 1993. Lobbying in the European Comunity. Oxford: Oxford University Press.

McConnell, G. 1966. Private Power and American Democracy. New York: Knopf.

Mills, C. W. 1956. The Power Elite. New York: Oxford University Press.

Moravcsik, A. 1993. 'Preferences and Power in the European Community. A Liberal Intergovernmentalist Approach', Journal of Common Market Studies 31, 473-524.

Moravcsik, A. 1998. The Choice for Europe. Social Purpose and State Power from Messina to Maastricht. Ithaca: Cornell University Press.

Nicolaidis, K. \& Howse, R., eds. Forthcoming. The Federal Vision. Legitimacy and Levels of Governance in the United States and the European Union. Oxford: Oxford University Press.

Olson, M. 1965. The Logic of Collective Action. Public Goods and the Theory of Groups. Cambridge, MA: Harvard University Press.

Pollack, M. A. 1997. 'Representing Diffuse Interests in EC Policy-Making', Journal of European Public Policy 4, 572-90.

Pollack, M. A. 2000. 'The End of Creeping Competence? EU Policy-Making since Maastricht', Journal of Common Market Studies 38, 519-38.

Rapoport, A. \& Guyer, M. J. 1966. 'A Taxonomy of $2 \times 2$ Games', General Systems 11, 203-14.

Rapoport, A., Guyer, M. J. \& Gordon, D. G. 1976. The $2 \times 2$ Game. Ann Arbor: University of Michigan Press.

Riker, W. H. 1964. Federalism. Origin, Operation, Significance. Boston: Little Brown.

Sabel, C. F. 1995. 'Learning by Monitoring. The Institutions of Economic Development', in Smelser, N. \& Swedberg, R., eds, Handbook of Economic Sociology. Princeton: Princeton University Press.

Sandholtz, W. \& Stone Sweet, A., eds. 1998. European Integration and Supranational Governance. Oxford: Oxford University Press.

Sandholtz, W. \& Stone Sweet, A. 1999. 'European Integration and Supranational Governance Revisited: Rejoinder to Branch and Øhrgaard', Journal of European Public Policy 6, $144-54$

Sbragia, A. M. 1992. 'Introduction', in Sbragia, A. M., ed., Euro-Politics. Institutions and Policymaking in the 'New' European Community. Washington: Brookings Institution.

Sbragia, A. M. 1993. 'The European Community: A Balancing Act', Publius 23(Summer), 23-38. 
Scharpf, F. W. 1988. 'The Joint Decision Trap. Lessons from German Federalism and European Integration', Public Administration 66, 239-78.

Scharpf, F. W. 1997. Games Real Actors Play. Actor-Centered Institutionalism in Policy Research. Boulder: Westview.

Scharpf, F. W. 1998. 'Globalisierung als Beschränkung der Handlungsmöglichkeiten nationalstaatlicher Politik', Jahrbuch für neue politische Ökonomie 17, 41-66.

Scharpf, F. W. 1999. Governing in Europe. Effective and Democratic? Oxford: Oxford University Press.

Scharpf, F. W. 2000. 'Interdependence and Democratic Legitimation', in Pharr, S. J. \& Putnam, R. D., eds, Disaffected Democracies. What's Troubling the Trilateral Countries? Princeton: Princeton University Press.

Scharpf, F. W. \& Schmidt, V. A., eds. 2000a. Welfare and Work in the Open Economy. Vol.1: From Vulnerability to Competitiveness. Oxford: Oxford University Press.

Scharpf, F. W. \& Schmidt, V. A., eds. 2000b. Welfare and Work in the Open Economy. Vol. 2: Diverse Responses to Common Challenges. Oxford: Oxford University Press.

Schmalz-Bruns, R. 1999. 'Deliberativer Supranationalismus. Demokratisches Regieren jenseits des Nationalstaats', Zeitschrift für Internationale Beziehungen 6, 185-244.

Schmidt, S. K. 1998. 'Commission Activism. Subsuming Telecommunications and Electricity under European Competition Law', Journal of European Public Policy 5, 169-84.

Schmidt, V. A. 1999. 'European Federalism and Its Encroachments on National Institutions', Publius 29, 19-44.

Schmitter, P. 1996. 'Imagining the Future of the Euro-Polity with the Help of New Concepts', in Marks, G., Scharpf, F. W., Schmitter, P. C. \& Streeck, W., eds, Governance in the European Union. London: Sage.

Schmitter, P. C. \& Lehmbruch, G., eds. 1979. Trends Toward Corporatist Intermeditation. London: Sage.

Sinn, H.-W. 1994. 'How Much Europe? Subsidiarity, Centralization and Fiscal Competition', Scottish Journal of Political Economy 41, 85-107.

Sinn, S. 1993. 'The Taming of Leviathan. Competition among Governments', Constitutional Political Economy 3, 177-221.

Skocpol, T. 1987. 'A Society without a "State"? Political Organization, Social Conflict, and Welfare Provision in the United States', Journal of Public Policy 7, 349-71.

Streeck, W. 1995. 'From Market Making to State Building? Reflections on the Political Economy of European Social Policy', in Leibfried, S. \& Pierson, P., eds, European Social Policy. Between Fragmentation and Integration. Washington: Brookings Institution.

Streeck, W. 1997. 'Industrial Citizenship under Regime Competition: The Case of the European Works Council', Journal of European Public Policy 4, 643-64.

Truman, D. B. 1951. The Governmental Process. Political Interests and Public Opinion. New York: Knopf.

Tsebelis, G. 1994. 'The Power of the European Parliament as a Conditional Agenda Setter', American Political Science Review 88, 128-42.

Vanberg, V. \& Kerber, W. 1994. 'Institutional Competition among Jurisdictions: An Evolutionary Approach', Constitutional Political Economy 5, 193-220.

Verdun, A. 1996. 'An "Asymmetrical" Economic and Monetary Union in the EU. Perceptions of Monetary Authorities and Social Partners', Journal of European Integration 20, 59-81.

Verdun, A. 2000. European Responses to Globalization and Financial Market Integration. Perceptions of Economic and Monetary Union in Britain, France and Germany. Houndmills: Macmillan.

Walker, N. 1998. 'Sovereignty and Differentiated Integration in the European Union', European Law Journal 4, 355-88.

Wallace, W. 1982. 'Europe as a Confederation: The Community and the Nation State', Journal of Common Market Studies 21, 57-68.

Weiler, J. H. H. 1982. 'The Community System: The Dual Character of Supranationalism', Yearbook of European Law 1, 257-306.

Weiler, J. H. H. 1999. 'Epilogue: "Comitology" as Revolution - Infranationalism, Constitutionalism and Democracy', in Joerges, C. \& Vos, E., eds, EU Committees: Social Regulation, Law and Politics. Oxford: Hart. 
Wessels, W. 1990. 'Administrative Interaction', in Wallace, W., ed., The Dynamics of European Integration. London: Pinter.

Wessels, W. 1997. 'An Ever Closer Fusion? A Dynamic Macropolitical View on Integration Processes', Journal of Common Market Studies 35, 267-99.

Wolf, D. 2000. 'Regelungsbefolgung auf verschiedenen politischen Ebenen. Wird nationales Recht wirklich besser befolgt als internationales Recht?', in van Deth, J. W. \& König, T., eds, Europäische Politikwissenschaft: Ein Blick in die Werkstatt. Frankfurt: Campus.

Zürn, M. 2000. 'Introduction - Law and Compliance at Different Levels'. Ms, Center for European Law and Policy, Universität Bremen. 